\title{
Aggregation with clay causes sedimentation of the buoyant cyanobacteria Microcystis spp.
}

\author{
Jolanda M. H. Verspagen ${ }^{1,2}$, Petra M. Visser ${ }^{1, *}$, Jef Huisman ${ }^{1}$ \\ ${ }^{1}$ Aquatic Microbiology, Institute for Biodiversity and Ecosystem Dynamics, University of Amsterdam, Nieuwe Achtergracht 127, \\ 1018 WS Amsterdam, The Netherlands \\ ${ }^{2}$ Department of Microbial Wetland Ecology, Netherlands Institute of Ecology (NIOO-KNAW), Centre for Limnology, \\ Rijksstraatweg 6, 3631 AC Nieuwersluis, The Netherlands
}

\begin{abstract}
We investigated whether the attachment of clay particles can result in sedimentation of the buoyant cyanobacteria Microcystis spp. For this purpose, we measured aggregation of clay to Microcystis spp. in field samples as well as in laboratory cultures of isolated strains. We focused on how the aggregation of clay to Microcystis spp. is affected by (1) the concentration of suspended clay particles, (2) the type of clay and (3) the stickiness and extracellular polysaccharide composition of these cyanobacteria. Our results show that aggregation of clay to Microcystis spp. is largely driven by mass action. The aggregation rate is proportional to the concentration of suspended clay particles. Experiments in a Couette chamber showed that aggregation of bentonite clay to Microcystis spp. is 15 to 22 times more efficient than aggregation of kaolinite clay. This reflects the difference in cation exchange capacity between these 2 clay minerals. Stickiness varied by more than 1 order of magnitude among different Microcystis strains, and showed a significant positive correlation with the amount of extracellular uronic acids in the slime layer of Microcystis spp. This indicates that uronic acids play an important role in aggregation, presumably through the formation of cation bridges. Our results imply that these buoyant cyanobacteria may undergo high sedimentation rates in lakes with high concentrations of suspended clay.
\end{abstract}

KEY WORDS: Coagulation · Flocculation · Benthic-pelagic coupling $\cdot$ Transparent exopolymer particles $\cdot$ TEP $\cdot$ Harmful algal blooms

Resale or republication not permitted without written consent of the publisher

\section{INTRODUCTION}

Sedimentation is a major loss process in the population dynamics of phytoplankton (Smayda 1970). Sedimentation rates of phytoplankton cells may increase through aggregation with other suspended particles. Examples include the aggregation and subsequent sedimentation of diatoms with transparent exopolymer particles (Kiørboe et al. 1990, 1994, Engel 2000), and the aggregation (sometimes also called flocculation) of phytoplankton cells with clay (Avnimelech et al. 1982, Søballe \& Threlkeld 1988). Aggregation with clay particles may even result in the sedimentation of buoyant phytoplankton species (Atkins et al. 2001).

The cyanobacteria Microcystis spp. are buoyant phytoplankton species that generally grow in colonies ranging in size from several tens to several thousands of cells. During periods of weak wind mixing, Microcystis spp. colonies float upwards and can form dense surface blooms in eutrophic freshwater ecosystems (Reynolds et al. 1981, Huisman et al. 2004, Visser et al. 2005). These surface blooms are a major nuisance in water quality management, because many Microcystis strains produce toxins that are harmful to zooplankton, fishes, birds, cattle, pets and even humans (Huisman et al. 2005). Microcystis spp. attain their buoyancy from intracellular gas vesicles filled with air (Walsby 1994). Despite their buoyant nature, however, large numbers can be found in lake sediments (Preston et al. 1980, Reynolds et al. 1981, Verspagen et al. 2005). Buoyant Microcystis colonies may accumulate sufficient ballast for sedimentation in at least 2 distinct ways: (1) their 
cells can store an excess of photosynthetic energy as carbohydrate ballast, which increases cell density and may thus cause the colonies to sink (Thomas \& Walsby 1985, Visser et al. 1995); (2) colonies may aggregate with suspended particles, which also increases their ballast, and may lead to sedimentation of the colonies (Oliver et al. 1985).

Which factors influence the aggregation of Microcystis spp. with suspended particles? Their colonies are imbedded in mucus, which consists mostly of extracellular polysaccharides (EPS) including high amounts of anionic sugars such as galacturonic acid (Plude et al. 1991). These EPS excreted by cyanobacteria may act as flocculants (Bar-Or \& Shilo 1988). Anionic sugars, in particular, are known to adsorb to negatively charged clay particles through cation bridges (Dontsova \& Bigham 2005). Similarly, Microcystis spp. mucus is known to adsorb cations (Plude et al. 1991). Therefore, it is quite likely that the anionic sugar-rich mucus that surrounds Microcystis spp. colonies facilitates aggregation with clay particles. However, since different Microcystis strains may contain different concentrations of anionic polysaccharides and since water bodies may differ in their amounts and types of clay and cations, sedimentation rates due to clay aggregation may show considerable variation across different aquatic ecosystems.

In this study, we investigated the sedimentation of Microcystis spp. arising from aggregation with suspended clay particles. For this purpose, we quantified the aggregation rates of clay to their colonies, using field samples consisting of complex mixtures of Microcystis strains as well as individual strains isolated from lake samples. We focused on how the aggregation of clay to Microcystis spp. is affected by (1) the concentration of suspended clay particles, (2) the type of clay and (3) the stickiness and EPS composition of these cyanobacteria.

\section{MATERIALS AND METHODS}

Study site. This study is part of a longer-term study of the population dynamics of Microcystis spp. in Lake Volkerak (Verspagen et al. 2004, 2005, 2006), a large water body of $45 \mathrm{~km}^{2}$, in the Dutch delta, SW Netherlands. Lake Volkerak is a former estuary that was closed off from the Eastern Scheldt and turned into a freshwater system in 1987. From the early 1990s onwards, the genus Microcystis has dominated the phytoplankton in this lake, and comprises more than $95 \%$ of the total phytoplankton biomass in summer. The Microcystis community of Lake Volkerak consists of different species. Most abundant are M. aeruginosa (Kützing) Kützing and M. flos-aqua (Wittrock) Kirchner, but smaller numbers of $M$. ichthyoblabe Kützing and $M$. viridis (A. Braun in Rabenhorst) have also been observed. During summer and autumn, large numbers of Microcystis spp. (hereafter Microcystis) sink and overwinter in the sediments (Verspagen et al. 2005, 2006), and benthic colonies buried in the sediments still contain gas vesicles and are thus buoyant when the aggregated sediments are removed (Verspagen et al. 2004). Microscopic observation revealed that clay particles and particulate organic matter were often attached to benthic and sinking colonies. The concentration of clay particles (particles $<2 \mu \mathrm{m}$ ) in Lake Volkerak, monitored during the years 2000 and 2001, ranged from 0.5 to $4 \mathrm{mg} \mathrm{l}^{-1}$ at the water surface (Netherlands Institute for Inland Water Management and Wastewater Treatment, public comm.). Concentrations of suspended matter typically increase with increasing water column depth, and can be 1 or 2 orders of magnitude higher in deep parts of the water column (Weyhenmeyer 1996). Detailed studies of the composition of the clays in Lake Volkerak are not available. However, the cation exchange capacity (CEC) of clay sediments in the Dutch delta area is typically $\sim 150$ meq $\mathrm{kg}^{-1}$ (De Koning et al. 2000). This resembles the CEC of kaolinite clay (Van Olphen 1977).

Theory. We developed a simple model on which to base our experiments, whereby $C$ denotes the concentration of clay minerals, $M$ the concentration of Microcystis colonies without clay, and $A$ the concentration of Microcystis colonies aggregated with clay. We assume that the aggregation rate of clay particles to Microcystis colonies is governed by mass action, i.e. it is proportional to the concentration of these colonies and the concentration of clay. Hence, a simple model of clay aggregation to Microcystis would be:

$$
\begin{aligned}
\frac{\mathrm{d} A}{\mathrm{~d} t} & =\beta M C-\gamma A \\
\frac{\mathrm{d} M}{\mathrm{~d} t} & =-\beta M C+\gamma A
\end{aligned}
$$

where $\beta$ is the specific aggregation rate of Microcystis and clay, and $\gamma$ is the specific disaggregation rate of the Microcystis-clay aggregates. The specific aggregation rate can be estimated from experiments with high concentrations of clay and Microcystis and very low concentrations of Microcystis-clay aggregates $(A \approx 0)$. In this case, according to Eqs. (1a) \& (1b), the concentration of Microcystis-clay aggregates should initially increase linearly in time $(t)$ :

$$
A(t)=\beta M C t
$$

We assume that clay aggregation is a fast process compared to the growth rate of the Microcystis population. In other words, within the time scale relevant for clay aggregation, the total concentration of Microcystis 
( $T=M+A)$ is assumed constant. Solving Eqs. (1a) \& (1b) for equilibrium, under the constraint $T=M+A$, yields the equilibrium concentration of Microcystis colonies aggregated with clay:

$$
A^{*}=\frac{T C}{C+\gamma / \beta}
$$

This equation shows that the equilibrium concentration of Microcystis-clay aggregates is a hyperbolic function of the clay concentration, with a slope $\beta T / \gamma$ at low clay concentrations and asymptotically approaching the total concentration of Microcystis ( $T$ ) at high clay concentrations. In analogy with Michaelis-Menten kinetics, the ratio of $\gamma / \beta$ will be called the half-saturation constant for clay aggregation.

Aggregation of Microcystis at different clay concentrations. In our first experiment, we incubated Strain V145, isolated from Lake Volkerak, with different concentrations of bentonite clay. Strain V145 was precultured in a flat culture vessel of a light-limited turbidostat (Huisman et al. 2002). In a turbidostat, the population density ('turbidity') is kept constant at a desired value, by adjusting the dilution rate until the desired population density is reached. In our case, the culture was maintained at an optical density at $750 \mathrm{~nm}$ $\left(\mathrm{OD}_{750}\right)$ of $0.2 \mathrm{~cm}^{-1}$ to yield a population density that was sufficiently high for the aggregation experiments. The culture was provided with a nutrient-rich mineral medium, containing $82 \mathrm{mg} \mathrm{l}^{-1} \mathrm{~N}$ and $4.4 \mathrm{mg} \mathrm{l}^{-1} \mathrm{P}$ (Van Liere \& Mur 1978). The culture was mixed homogeneously by flushing with air at a low flushing intensity to prevent disruption of colonies. Temperature was maintained at $25^{\circ} \mathrm{C}$ by a water jacket placed against the culture vessel. Light was provided by 4 fluorescent tubes (Philips PLL 24 W/84), arranged adjacent to each other to cover the full front of the culture vessel. Light intensities (photosynthetically active radiation, PAR, from 400 to $700 \mathrm{~nm}$ ) were measured with a LI-190SA quantum sensor (LI-COR). The incident light intensity $\left(I_{\mathrm{IN}}\right)$ and the light intensity penetrating the cultures $\left(I_{\text {OUT }}\right)$ were measured at the surface at the front and back of the culture vessels, respectively. Average light intensity $\left(I_{\mathrm{AV}}\right)$ in the cultures was calculated according to Lambert-Beer's law as:

$$
I_{\mathrm{AV}}=\frac{I_{\mathrm{IN}}-I_{\mathrm{OUT}}}{\ln \left(I_{\mathrm{IN}}\right)-\ln \left(I_{\mathrm{OUT}}\right)}
$$

We used an average light intensity of $120 \mu \mathrm{mol}$ photons $\mathrm{m}^{-2} \mathrm{~s}^{-1}$ during the light period and a light:dark period of 14:10 h.

Aggregation of Microcystis with clays was estimated from the concentration of sinking cells. In the dark, Microcystis gain buoyancy by respiration of their carbohydrate ballast (Thomas \& Walsby 1985). Samples were taken from the turbidostat at the end of the dark period, to ensure that nearly all Microcystis cells were buoyant. The samples were diluted with mineral medium to a concentration of $\sim 70000$ cells ml-1. These diluted samples were placed in 0.51 measuring cylinders (height $=22.5 \mathrm{~cm}$, diameter $=5.0 \mathrm{~cm}$ ), in the dark, with 3 different bentonite clay concentrations $(0.25$, 0.50 and $0.75 \mathrm{~g} \mathrm{l}^{-1}$ ). These clay concentrations are likely to be of a similar order of magnitude as the clay concentrations near the sediment bed of Lake Volkerak, since concentrations of suspended matter are typically 1 or 2 orders of magnitude higher near the sediment than in surface water (Weyhenmeyer 1996). At the start of the experiment, $10 \mathrm{~g}$ of clay was dispersed in $100 \mathrm{ml}$ of demineralised water, and a proper volume of this clay slurry was added to the cylinder using a pipette. The clay particles and Microcystis colonies were mixed by sealing the cylinder with parafilm and gently turning it upside-down 3 times. Since the experiments were carried out in the dark, thus preventing carbohydrate accumulation, sinking of buoyant Microcystis colonies can be attributed to the attachment of clay. Hence, we monitored the concentration of sinking Microcystis cells as an indication of the concentration of Microcystis-clay aggregates (A). For this purpose, the cylinder was sampled at regular time intervals. Sampling was carried out as long as the concentration of Microcystis particles and the clay concentration (measured as $\mathrm{OD}_{750}$ ) remained more or less constant $(\sim 5 \mathrm{~h})$, indicating that the mixture in the cylinder was homogeneously distributed. Samples were taken once or twice per hour at a depth of $12.5 \mathrm{~cm}$ using a pipette with its tip cut off to avoid disruption of the cell aggregates. The tip opening had a diameter of $0.5 \mathrm{~cm}$. The samples were transferred to a Sedgewick-Rafter counting chamber, and were allowed to settle for at least $10 \mathrm{~min}$ before the number of buoyant and sinking Microcystis particles (cells and colonies) was counted. We used a fluorescence microscope with a filter that only emits light with a wavelength $>470 \mathrm{~nm}$, showing chlorophyll a fluorescence to discern sinking Microcystis particles from clay particles. To obtain statistically reliable results, at least 400 particles or 100 grids of the counting chamber were counted.

Aggregation of Microcystis with different types of clay. To investigate how aggregation of clay to Microcystis depends on the type of clay, we incubated field samples of Microcystis with different concentrations of kaolinite clay $\left(\mathrm{Al}_{2} \mathrm{O}_{7} \mathrm{Si}_{3} \cdot 2 \mathrm{H}_{2} \mathrm{O}, 286.25 \mathrm{~g} \mathrm{~mol}^{-1}\right.$; Fluka Chemie) and bentonite clay $\left(\mathrm{Al}_{2} \mathrm{O}_{3} \cdot 4 \mathrm{SiO}_{2} \cdot \mathrm{H}_{2} \mathrm{O}\right.$, $360.31 \mathrm{~g} \mathrm{~mol}^{-1}$; Sigma-Aldrich Chemie). The particle size distributions of the 2 clays were quite similar, in the range 3 to $25 \mu \mathrm{m}$ for kaolinite and 2 to $15 \mu \mathrm{m}$ for bentonite. The 2 clays differ in their CEC, which is 30 to 150 meq $\mathrm{kg}^{-1}$ for kaolinite and 700 to $1000 \mathrm{meq} \mathrm{kg}^{-1}$ for bentonite clay (Van Olphen 1977). 
Microcystis colonies were sampled from the surface water of Lake Volkerak on 22 July and 18 August 2003. Field samples were stored overnight in the dark. The following day, aggregation experiments were carried out in a Couette chamber in complete darkness to assure maximum buoyancy of the Microcystis colonies during the experiments. A Couette chamber consists of an outer rotating cylinder and an inner fixed cylinder with fluid between the two. Rotation of the outer cylinder produces laminar shear of the fluid and leads to collision of suspended particles (Kiørboe et al. 1990, Drapeau et al. 1994). Mean shear $\left(G_{\mathrm{M}}\right.$ in $\left.\mathrm{s}^{-1}\right)$ in a Couette chamber can be calculated according to Van Duuren (1968) as:

$$
G_{\mathrm{M}}=\frac{4 \pi \omega r_{2} r_{1}}{\left(r_{2}^{2}-r_{1}^{2}\right)}
$$

where $r_{2}$ and $r_{1}$ are the radii $(\mathrm{cm})$ of the outer and inner cylinder, and $\omega$ is the angular velocity $\left(\mathrm{s}^{-1}\right)$. Our Couette chamber was designed according to Drapeau et al. (1994). It had a total length of $17 \mathrm{~cm}$, with an outer radius of $5.5 \mathrm{~cm}$ and an inner radius of $4.4 \mathrm{~cm}$. About 0.61 of sample was incubated within the space between the 2 cylinders. In all experiments, $G_{M}$ was set at $31 \mathrm{~s}^{-1}$. We incubated the field samples in a Couette chamber for $30 \mathrm{~min}$, using a range of different clay concentrations ( 0 to $5 \mathrm{~g} \mathrm{l}^{-1}$ ). After incubation, the number of buoyant and sinking Microcystis cells was counted as described in the previous subsection. Again, the concentration of sinking cells was used as an indication of the concentration of Microcystis-clay aggregates.

Stickiness and polysaccharide composition. Cultures of isolated strains: To investigate whether the stickiness of Microcystis is affected by the composition of EPS, we selected 5 strains (V40, V101, V130, V145 and V163) isolated from Lake Volkerak. According to microscopic inspection with $10 \%$ Indian ink, these strains differed in the amount and morphology of their mucus. The strains were cultured in a nutrient-rich mineral medium (Van Liere \& Mur 1978). Strains V40, V101, V145 and V163 were grown in batch cultures on a rotation table at a low light intensity of $10 \mu \mathrm{mol}$ photons $\mathrm{m}^{-2} \mathrm{~s}^{-1}$ and a light:dark cycle of 12:12 h. Strain V130 was grown under similar conditions, at 3 different light intensities of 10, 50 and $140 \mu \mathrm{mol}$ photons $\mathrm{m}^{-2} \mathrm{~s}^{-1}$, respectively.

Stickiness: Stickiness $(\alpha)$ can be defined as the probability that 2 colliding particles stick together, with values ranging from -1 to 1 . Negative stickiness indicates that particles fall apart when they collide, whereas positive values indicate that particles adhere when they collide. We measured the stickiness of the selected Microcystis strains by studying the formation of cell aggregates after suspension of individual cells in a laminar shear field generated by a Couette chamber.
Let $P$ denote the concentration of Microcystis particles (= individual cells + aggregates). Furthermore, let $\phi=N d^{3} \pi / 6$ denote the fraction of the total water volume that is occupied by Microcystis, where $N$ is the concentration of Microcystis cells (= individual cells + cells in aggregates) and $d$ is the diameter of a cell. If we consider a solution that initially consists of individual Microcystis cells, then aggregation of these individual cells into larger aggregates leads to a decline in the number of particles within the Couette chamber. The initial phase of this decline can be described by the following equation (McCave 1984, Kiørboe et al. 1990):

$$
P_{t}=P_{0} \exp \left(-2,49 \alpha \phi G_{\mathrm{M}} t\right)
$$

Hence, the stickiness of Microcystis can be calculated by solving Eq. (6) for $\alpha$.

Before incubation in the Couette chamber, the gas vesicles of Microcystis cells were collapsed by exposing them to a pressure of 10 bar (Walsby 1994). Cultures were diluted in mineral medium (Van Liere \& Mur 1978), such that the volume fraction occupied by Microcystis ranged between $\phi=0.5 \times 10^{-6}$ and $8.7 \times$ $10^{-6}$. Microcystis samples were incubated in the Couette chamber for $0,15,30,60,90,120$ and $150 \mathrm{~min}$. After incubation, the number of Microcystis particles $\left(P_{t}\right)$ was counted microscopically as described in previous subsection.

In each sample, the volume fraction of Microcystis $(\phi)$ was determined by breaking up Microcystis colonies into single cells. For this purpose, samples were washed with a sucrose solution with the same osmotic value as the nutrient-rich mineral medium $\left(0.6 \mathrm{~g} \mathrm{l}^{-1}\right.$ sucrose). Since the sucrose solution does not contain electrolytes to form cation bridges, the Microcystis colonies disaggregate into single cells. The concentration of cells $(\mathrm{N})$ in the sample was determined microscopically in a Fuchs-Rosental counting chamber designed for counting single cells. The average diameter of the cells $(d)$ was determined by measuring the diameter of 100 single cells using 'Image Analysis Software' (Leica Qwin Standard Version 2.5).

Polysaccharide composition: EPS attached to Microcystis particles were isolated according to Staats et al. (1999). Samples were centrifuged at $15000 \mathrm{rpm}$ $(27000 \times g)$ for $30 \mathrm{~min}$ at $10^{\circ} \mathrm{C}$ to pellet both cells and EPS. The supernatant was removed, and the pellet was dissolved in demineralised water (Plude et al. 1991) and incubated for $2 \mathrm{~h}$ at $40^{\circ} \mathrm{C}$. Subsequently, the samples were centrifuged for $10 \mathrm{~min}$ at $4000 \mathrm{rpm}$ $(46000 \times g)$ to pellet the cells only, while EPS were retained in the supernatant. The supernatant was transferred to another tube. The pellet was dissolved again in demineralised water and incubated for $2 \mathrm{~h}$ at $40^{\circ} \mathrm{C}$. This procedure to 'wash off' all EPS was repeated 3 to 4 times until EPS were no longer observed 
in the pellet. The disappearance of EPS from the pellet was checked microscopically by dying the dissolved pellet with Indian ink $(10 \%)$. Before analysis, the supernatant containing all EPS was lyophilised and dissolved in a fixed amount of demineralised water. The concentration of EPS was analysed using the phenol $/ \mathrm{H}_{2} \mathrm{SO}_{4}$ assay (Dubois et al. 1956) with glucose as a standard. Extracellular uronic acids (EUA) were analysed using the method of Blumenkrantz \& AsboeHansen (1973) with glucoronic acid as a standard.

Effect of light conditions on polysaccharide composition. We selected Microcystis Strain V145 to perform further experiments on the effect of light conditions on polysaccharide composition. Strain V145 was cultured in flat vessels using light-limited turbidostats with a similar set-up as described above. The turbidostats were exposed to 5 different average light intensities $\left(10,20,45,70\right.$ and $120 \mu \mathrm{mol}$ photons $\left.\mathrm{m}^{-2} \mathrm{~s}^{-1}\right)$ during the light period, by placing neutral density filters between the light source and the culture vessels. We used a light:dark cycle of 14:10 h. After about 1 to $2 \mathrm{wk}$, when the turbidostats had reached a steady state with an optical density of $0.2 \mathrm{~cm}^{-1}$, they were sampled just before the onset of the light period. EPS and EUA were isolated and quantified as described above.

\section{RESULTS}

\section{Aggregation of Microcystis at different clay concentrations}

To obtain buoyant Microcystis colonies for the aggregation experiments, we sampled Microcystis Strain V145 from a turbidostat at the end of the dark period, thus ensuring a high concentration of buoyant cells and a low concentration of sinking cells. As a control, we first inoculated Strain V145 in a measuring cylinder without adding clay. The concentration of sinking cells in this control experiment did not increase over time. Next, we inoculated Strain V145 in 3 measuring cylinders, and added 3 different concentrations of clay. As predicted by Eq. (2), when clay was added, the concentration of sinking cells initially increased linearly over time (Fig. 1; linear regression at $0.25 \mathrm{~g} \mathrm{l}^{-1}$ clay: $\mathrm{r}^{2}=0.824, \mathrm{~N}=7, \mathrm{p}<0.005$; at $0.50 \mathrm{~g} \mathrm{l}^{-1}$ clay: $\mathrm{r}^{2}=0.877, \mathrm{~N}=9, \mathrm{p}<0.001$; at $0.75 \mathrm{~g} \mathrm{l}^{-1}$ clay: $\left.\mathrm{r}^{2}=0.920, \mathrm{~N}=5, \mathrm{p}<0.010\right)$. The experiments further show that the aggregation rate was linearly proportional to the clay concentration (Fig. 1), which is also in accordance with Eq. (2). From the data presented in Fig. 1, we calculated a specific clay aggregation rate of $\beta=A /(M C t)=27 \mathrm{ml}$ (g bentonite clay) ${ }^{-1} \mathrm{~h}^{-1}$.

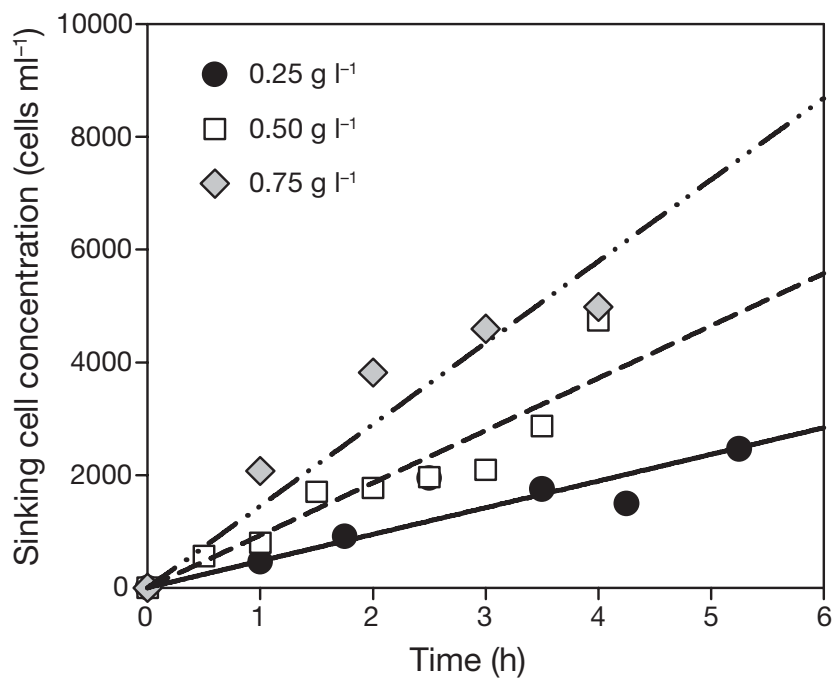

Fig. 1. Microcystis Strain V145. Aggregation of cyanobacterium and bentonite clay in a measuring cylinder. Concentration of sinking cells as a function of time for 3 clay concentrations. Lines indicate fit of data to Eq. (2) using linear regression forced through origin

\section{Aggregation of Microcystis with different types of clay}

The Microcystis populations sampled in Lake Volkerak on 22 July and 18 August 2003 differed in the concentration of Microcystis colonies and in colony size. The sample of 22 July was characterized by a small number of large colonies (3100 colonies $\mathrm{ml}^{-1}$ with an average colony size of 447 cells), while the sample of 18 August had a large number of small colonies (18 000 colonies $\mathrm{ml}^{-1}$ with an average colony size of 58 cells).

Aggregation experiments in the Couette chamber showed that the steady-state concentration of sinking Microcystis cells $\left(A^{*}\right)$ increased with increasing clay concentration $(C)$ in accordance with the hyperbolic relationship described by Eq. (3) (Table 1, Fig. 2). The asymptotic values reached on 22 July were lower than the asymptotic values reached on 18 August (Fig. 2), which reflects the observed differences in the total concentration of colonies $(T)$ on these 2 days. Half-saturation constants for clay aggregation $(\gamma / \beta)$ were 22 times lower for bentonite clay than for kaolinite clay on 22 July and 15 times lower on 18 August) (Table 1). Hence, clay aggregation was much more efficient with bentonite clay than with kaolinite clay.

\section{Stickiness and polysaccharide composition}

Most Microcystis strains aggregated into larger particles in the Couette chamber. As a result, the concentration of Microcystis particles in the Couette chamber 
Table 1. Microcystis spp. Parameter estimates of Eq. (3), describing equilibrium concentration of sinking cells as a hyperbolic function of clay concentration. Parameter estimates were obtained by nonlinear regression. Experiments were carried out with field samples of Microcystis and 2 types of clay. $K_{\mathrm{S}}$ : half-saturation constant; $\gamma$ : specific disaggregation rate of Microcystis-clay aggregates; $\beta$ : specific aggregation rate of Microcystis and clay

\begin{tabular}{|c|c|c|c|c|c|}
\hline $\begin{array}{l}\text { Sampling day } \\
\text { (2003) }\end{array}$ & $\begin{array}{l}\text { Total Microcystis } \\
\left(\times 10^{6} \text { cells ml }^{-1}\right)\end{array}$ & $\begin{array}{c}K_{\mathrm{S}} \\
\left(\gamma / \beta, \mathrm{g} \mathrm{l}^{-1}\right)\end{array}$ & $r^{2}$ & $\mathrm{~N}$ & $\mathrm{p}$ \\
\hline \multicolumn{6}{|l|}{ Kaolinite } \\
\hline 22 Jul & 2.59 & 0.869 & 0.84 & 10 & 0.0002 \\
\hline 18 Aug & 4.31 & 0.244 & 0.85 & 9 & 0.0004 \\
\hline \multicolumn{6}{|l|}{ Bentonite } \\
\hline $22 \mathrm{Jul}$ & 0.62 & 0.039 & 0.80 & 8 & 0.0028 \\
\hline $18 \mathrm{Aug}$ & 2.23 & 0.016 & 0.98 & 10 & $<0.0001$ \\
\hline
\end{tabular}

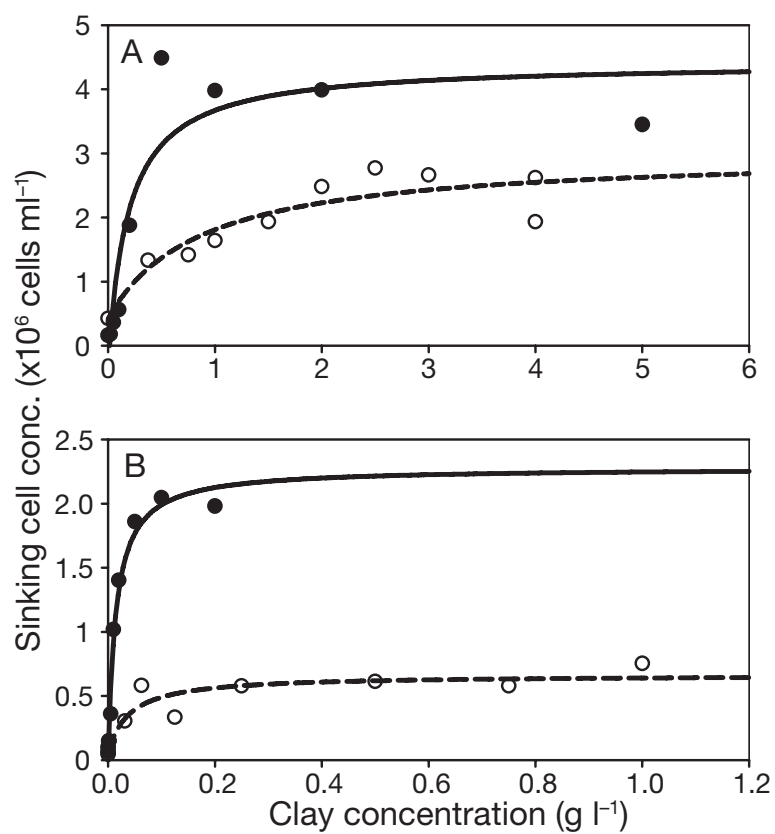

Fig. 2. Microcystis spp. Aggregation of field samples with (A) kaolinite clay and (B) bentonite clay in a Couette chamber. Equilibrium concentration of sinking cells as a function of clay concentration. Samples were taken from Lake Volkerak on 22 July (O) and 18 August 2003 (0). Lines indicate fit of data to Eq. (3), using nonlinear regression

declined exponentially over time, in accordance with Eq. (6) (Fig. 3A). There was 1 exception: Strain V130 grown at $10 \mu \mathrm{mol}$ photons $\mathrm{m}^{-2} \mathrm{~s}^{-1}$ did not aggregate, but disintegrated into smaller particles. Stickiness calculated from Eq. (6) ranged from $\alpha=-0.20$ for Strain V130 grown at $10 \mu \mathrm{mol}$ photons $\mathrm{m}^{-2} \mathrm{~s}^{-1}$ to $\alpha=0.47$ for Strain V163 (Fig. 3B).

The concentration of EPS ranged from 81 to $720 \mu \mathrm{g}$ $(\mu \text { l biovolume })^{-1}$ (= 8.6 to 67 pg cell $^{-1}$ ) and the concen- tration of extracellular uronic acids (EUA) ranged from 6.3 to $107 \mu \mathrm{g}$ ( $\mu \mathrm{l}$ biovolume $)^{-1}$ (= 0.6 to $10 \mathrm{pg} \mathrm{cell}^{-1}$ ). In all strains, 7 to $25 \%$ of EPS consisted of uronic acids. We investigated whether there was a correlation between polysaccharide composition and stickiness. For this purpose, the EPS and EUA data were logtransformed to obtain bivariate normal distributions required for a Pearson's correlation test. There was no significant correlation between stickiness and the logtransformed amount of EPS per biovolume (Pearson's correlation, $r=0.632, N=7, p=0.128$ ). However, we found a significant correlation between stickiness and the log-transformed amount of EUA per biovolume (Pearson's correlation, $\mathrm{r}=0.783, \mathrm{~N}=7, \mathrm{p}<0.05$; Fig. 3B).
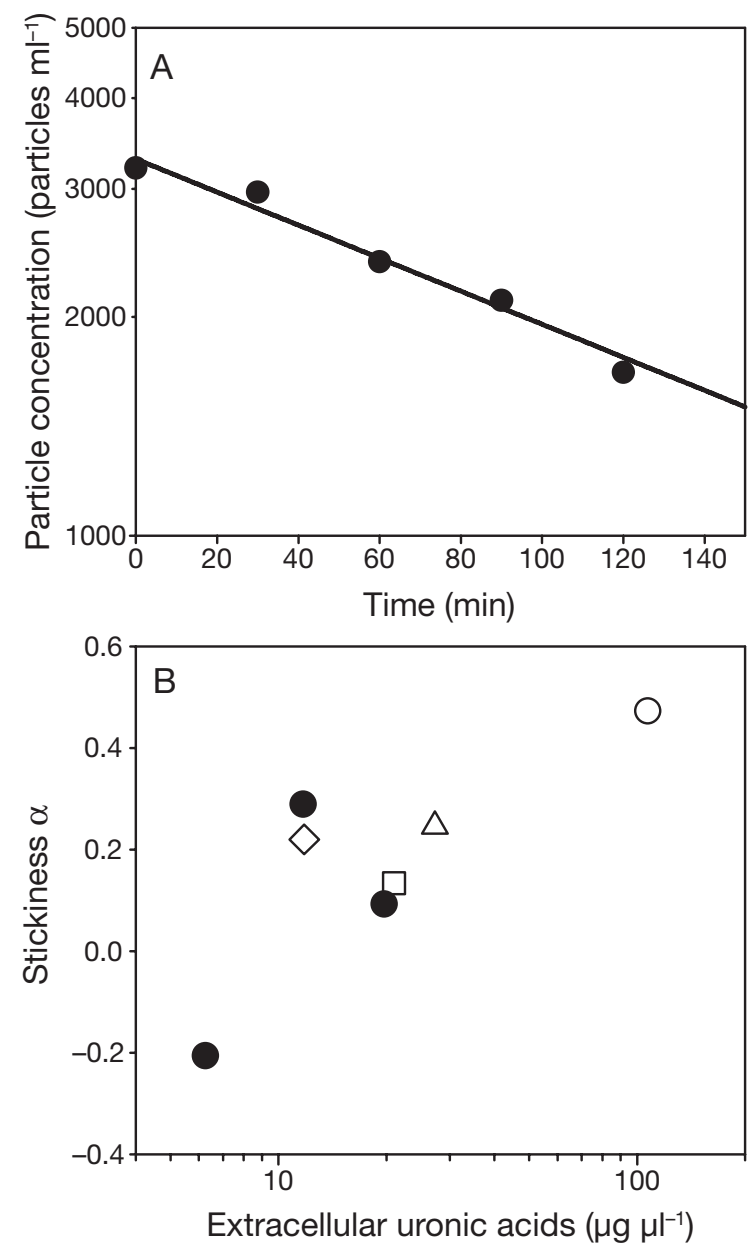

Fig. 3. Microcystis spp. Stickiness of various strains. (A) Exponential decline in particle concentration of Microcystis Strain V145 in a Couette chamber arising from formation of larger aggregates; line indicates fit of data to Eq. (6) using linear regression after log transformation of the particle concentration. (B) Stickiness of different Microcystis strains as a function of concentration of extracellular uronic acid per biovolume: Strain V40 $(\square)$, Strain V101 $(\triangle)_{\text {; }}$ Strain V130 $(\bullet)$; Strain V145 $(\diamond)$; Strain V163 (O) 


\section{Effect of light conditions on polysaccharide composition}

The specific growth rate $(\mu)$ of Microcystis Strain V145 increased with increasing light intensity up to an average light intensity of $70 \mu \mathrm{mol}$ photons $\mathrm{m}^{-2} \mathrm{~s}^{-1}$ and then remained fairly constant until at least $120 \mu \mathrm{mol}$ photons $\mathrm{m}^{-2} \mathrm{~s}^{-1}$ (Fig. 4A). The response of the concentration of EPS to light intensity was similar to that of $\mu$, while the concentration of EUA was little affected by light intensity (Fig. 4B). As a consequence, the proportion of uronic acids in EPS strongly declined with increasing light intensity, from more than $60 \%$ at low light intensity to $20 \%$ at high light intensity (Fig. 4C).

\section{DISCUSSION}

In this study we found that aggregation of clay particles may cause sedimentation of the buoyant cyanobacteria Microcystis. Aggregation of clay to Microcystis depends on several factors, including the concentration of suspended clay particles, type of clay, and the composition of EPS of Microcystis.

\section{Clay concentration}

Our results show that aggregation of clay to Microcystis is largely driven by mass action, i.e. the aggregation rate is linearly proportional to the concentration of suspended clay particles (Fig. 1). Microcystis-clay aggregates may disaggregate when exposed to high shear. Under constant conditions, the balance between aggregation and disaggregation processes leads to an equilibrium concentration of Microcystis-clay aggregates. Our simple model shows that, as a first approximation, the equilibrium concentration of Microcystisclay aggregates can be expressed as a hyperbolic function of the clay concentration. This prediction is supported by our experiments with Microcystis and clay in the Couette chamber (Fig. 2). A similar hyperbolic relationship has been reported for clay aggregation to marine dinoflagellates by Sengco et al. (2001).

\section{Type of clay}

Several properties of suspended clay affect aggregation of clay and algae, including clay particle size, the surface charge (zeta potential) of clay, and the ionic strength and $\mathrm{pH}$ of the water in which clay and algae are suspended (Han \& Kim 2001, Sengco et al. 2001). Here, we focused on the difference between bentonite and kaolinite clay. The experiments in the Couette chamber
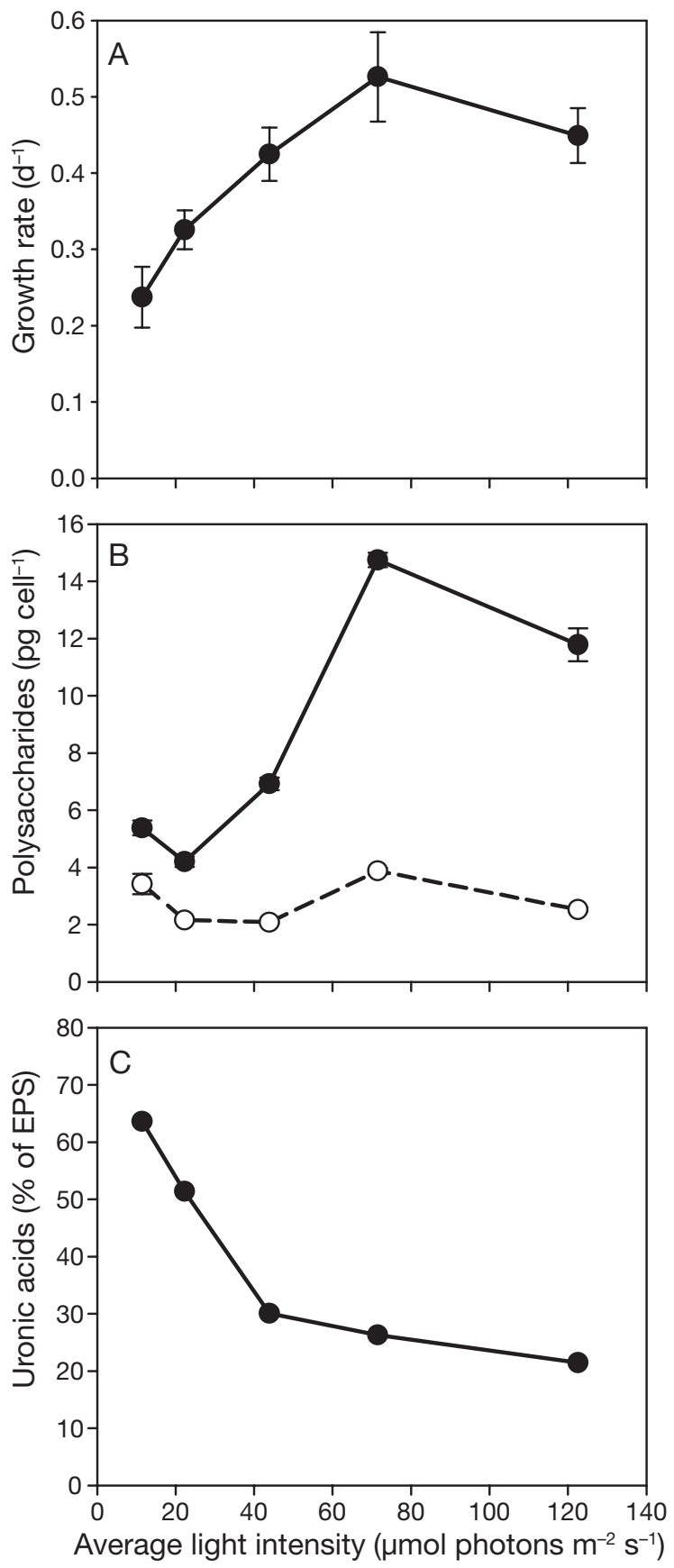

Fig. 4. Microcystis Strain V145. (A) Specific growth rate and (B) cellular concentration of extracellular polysaccharides (EPS) (-) and extracellular uronic acids (EUA) (O) of bacterium cultured at different light intensities; error bars represent $\pm 1 \mathrm{SE} ; \mathrm{N}=7$ for (A) and 4 for (B). (C) Relative contribution of uronic acids to extracellular polysaccharides

show that aggregation of bentonite clay to Microcystis is 15 to 22 times more efficient than aggregation of kaolinite clay. Bentonite concentrations as low as $15 \mathrm{mg} \mathrm{l}^{-1}$ resulted in increased sedimentation of Microcystis, whereas kaolinite concentrations of $\sim 200 \mathrm{mg} \mathrm{l}^{-1}$ would 
be required for the same effect. Similar differences have been observed in sedimentation of phytoplankton in incubations with kaolinite and bentonite clay (Søballe \& Threlkeld 1988, Sengco et al. 2001). The difference in aggregation efficiency between the 2 clays reflects a difference in the structure of these clays. Bentonite clays consist of 1 aluminium octahedral layer sandwiched between 2 silicon tetrahedral layers. The plates formed by these 3-layered clay minerals are held together by weak van der Waals' bonds, which allow cations to move freely in and out between the plates. In contrast, kaolinite clays consist of 1 aluminium octahedral layer and 1 silicon tetrahedral layer. The plates formed by these 2-layered structures are tightly held together by strong hydrogen bonds. As a result, the CEC of bentonite is 5 to 30 times higher than that of kaolinite (Van Olphen 1977), which nicely matches the difference in aggregation efficiency of these clays with Microcystis.

\section{Stickiness of Microcystis}

Stickiness of Microcystis strains isolated from Lake Volkerak ranged from -0.20 to 0.47 , whereby stickiness of 0.47 means that $47 \%$ of the particle collisions resulted in aggregation. So far, we are not aware of other studies on the stickiness of cyanobacteria. Our stickiness values for Microcystis fit quite well, however, with those reported for marine diatoms (Table 2).

Stickiness of phytoplankton is often attributed to EPS and other transparent exopolymers (e.g. Kiørboe \& Hansen 1993, Engel 2000). The Microcystis strains used in this study differed widely in their EPS production, ranging from 4 to $66 \mathrm{pg}$ EPS cell ${ }^{-1}$. Contrary to expectation, we did not find a significant relation between the concentration of (EPS) and the stickiness of the strains. Rather than the concentration of EPS per se, our results indicate that the chemical composition of EPS plays a crucial role in aggregation. In particular, part of the EPS produced by cyanobacteria consists of uronic acids (De Philippis et al. 2001). Uronic acids are anionic sugars that can form cation bridges with negatively charged clay particles and with other anionic sugars (Dontsova \& Bigham 2005). The hypothesis that anionic sugars are involved in aggregation of Microcystis cells is supported by the positive correlation between stickiness and the amount of EUA produced by the different Microcystis strains (Fig. 3B).

The stickiness of Microcystis is affected by ambient nutrient and light conditions. The uronic acid content of the EPS of Strain V145 decreased with increasing light intensity (Fig. 4C). This suggests that Strain V145 would be most sticky at low light. Strycek et al. (1992) reported that phosphorus limitation increases the production of EUA of $M$. aeruginosa. Moreover, stickiness also varies by more than 1 order of magnitude among different Microcystis strains grown under identical conditions (Fig. 3B). Hence, there is considerable variability in stickiness within and among strains.

\section{Ecological implications}

In some lakes, large amounts of Microcystis overwinter in the sediment (Preston et al. 1980, Takamura et al. 1984, Verspagen et al. 2005). Visser et al. (1995) showed that low temperatures lead to an increased carbohydrate ballast of Microcystis, which may cause sedimentation of Microcystis colonies in autumn. Using sediment traps, however, we observed that sedimentation of Microcystis colonies in Lake Volkerak occurs throughout the summer period (Verspagen et al. 2005). Moreover, freshly sedimented colonies were buoyant after removal of attached sediment particles (Verspagen et al. 2004). This indicated that, in Lake Volkerak, sedimentation is not driven by an increase in the carbohydrate ballast, but rather by aggregation with suspended particles. Indeed, the present study confirms that buoyant Microcystis colonies may suffer high sedimentation losses due to aggregation with clay, even after respiration of all their carbohydrate ballast. Concentrations of suspended clay can show considerable variability in time, and may increase when storms resuspend the sediments of shallow lakes or when heavy rainfalls generate run-off of sediments from the surrounding watershed into lakes. We therefore hypothesise that peak loadings with clay particles, after periods of heavy storms or rainfall, may cause massive sedimentation of Microcystis blooms.

Table 2. Microcystis spp. Stickiness compared to stickiness of various marine diatom species. Measurements were performed in laboratory monocultures (1), in samples from natural bloom (n), and in natural bloom incubated in mesocosmos (n.m)

\begin{tabular}{|lrl|}
\hline Species & \multicolumn{1}{c}{ Stickiness } & \multicolumn{1}{c|}{ Source } \\
\hline Chaetoceros neogracile (l) & $0.000-0.017$ & Waite et al. (1997) \\
Thalassiosira pseudonana (l) & $0.001-0.050$ & Kiørboe et al. (1990) \\
Skeletonema costatum (l) & $0.015-0.150$ & Kiørboe et al. (1990) \\
Phaeodactylum tricornutum (l) & $0.040-0.200$ & Kiørboe et al. (1990) \\
Microcystis spp. (l) & $-0.200-0.470$ & Present study \\
Skeletonema costatum (l) & $0.100-0.600$ & Hansen \& Kiørboe (1997) \\
Thalassiosira nordenskjoeldii (l) & $0.100-0.700$ & Hansen \& Kiørboe (1997) \\
Chaetoceros spp. (n.m) & $0.030-0.800$ & Dam \& Drapeau (1995) \\
Skeletonema costatum (n) & $<0.100-1.000$ & Engel (2000) \\
\hline
\end{tabular}


Sedimentation of algal cells through flocculation with clay is a promising control strategy for removal of harmful algal blooms (Anderson 1997, Sengco et al. 2001, Hagström \& Granéli 2005). Similarly, flocculation with clay might be a useful method for controlling Microcystis blooms. However, in a field study in which clay particles (a bentonite clay and polyaluminium chloride mixture) were added to a natural Microcystis bloom in the Swan River, this method was not effective (Atkins et al. 2001). Apparently, the conditions in the Swan River were not favourable for flocculation of Microcystis. As confirmed by our findings, the aggregation efficiency with clay depends on many variables, including algal cell concentrations, clay type and clay concentration, and physiological status of the cells (Avnimelech et al. 1982, Hagström \& Granéli 2005, Sengco et al. 2005). Further field trials in which clay is added to natural Microcystis blooms are recommended.

Our results further show that there is a large variability in polysaccharide composition and stickiness among different Microcystis strains. Some strains aggregate very easily, whereas other strains do not aggregate at all. It is thus conceivable that high concentrations of suspended clay might select for Microcystis strains with a low stickiness. Natural selection might partly counteract the flocculation of Microcystis blooms. This intriguing interplay between clay dispersal and the population dynamics of different Microcystis strains seems to deserve further investigation.

Acknowledgements. Special thanks to the crew of the RV 'de Argus' for assistance with field sampling, to W. E. A. Kardinaal and J. Snoek for isolating numerous Microcystis strains from Lake Volkerak, and to E. Cruz Calpe for measuring stickiness. The research of J.M.H.V. was funded by the Netherlands Institute of Ecology and the University of Amsterdam. The investigations of P.M.V. and J.H. were supported by the Earth and Life Sciences Foundation (ALW), which is subsidised by the Netherlands Organization for Scientific Research (NWO).

\section{LITERATURE CITED}

Anderson DM (1997) Turning back the harmful red tide. Nature 388:513-514

Atkins R, Rose T, Brown RS, Robb M (2001) The Microcystis cyanobacteria bloom in the Swan River-February 2000. Water Sci Technol 43:107-114

Avnimelech Y, Troeger BW, Reed LW (1982) Mutual flocculation of algae and clay: evidence and implications. Science 216:63-65

Bar-Or Y, Shilo M (1988) The role of cell-bound flocculants in coflocculation of benthic cyanobacteria with clay particles. FEMS Microbiol Ecol 53:169-174

Blumenkrantz N, Asboe-Hansen G (1973) New method for quantitative determination of uronic acids. Anal Biochem 54:484-489

Dam HG, Drapeau DT (1995) Coagulation efficiency, organic matter glues and the dynamics of particles during a phyto- plankton bloom in a mesocosm study. Deep-Sea Res II 42: 111-123

De Koning A, Geelhoed-Bonouvrie PA, Coma RNJ (2000) Comparing in situ distribution coefficients and exchangeability of radiocaesium in freshwater sediments with laboratory predictions. Sci Total Environ 257:29-35

De Philippis R, Sili C, Paperi R, Vincenzini M (2001) Exopolysaccharide-producing cyanobacteria and their possible exploitation: a review. J Appl Phycol 13:293-299

Dontsova KM, Bigham JM (2005) Anionic polysaccharide sorption by clay minerals. Soil Sci Soc Am J 69:1026-1035

Drapeau DT, Dam HG, Grenier G (1994) An improved flocculator design for use in particle aggregation experiments. Limnol Oceanogr 39:723-729

Dubois M, Gilles KA, Hamilton JK, Rebers PA, Smith F (1956) Colorimetric methods for determination of sugars and related substances. Anal Chem 28:350-356

Engel A (2000) The role of transparent exopolymer particles (TEP) in the increase in apparent particle stickiness $(\alpha)$ during the decline of a diatom bloom. J Plankton Res 22: 485-497

Hagström JA, Granéli E (2005) Removal of Prymnesium parvum (Haptophyceae) cells under different nutrient conditions by clay. Harmful Algae 4:249-260

Han MY, Kim W (2001) A theoretical consideration of algae removal with clays. Microchem J 68:157-161

Hansen JLS, Kiørboe T (1997) Quantifying the interspecific coagulation efficiency of phytoplankton. Mar Ecol Prog Ser 159:75-79

Huisman J, Matthijs HCP, Visser PM, Balke H, Sigon CAM, Passarge J, Weissing FJ, Mur LR (2002) Principles of the light-limited chemostat: theory and ecological applications. Antonie Leeuwenhoek 81:117-133

Huisman J, Sharples J, Stroom JM, Visser PM, Kardinaal WEA, Verspagen JMH, Sommeijer B (2004) Changes in turbulent mixing shift competition for light between phytoplankton species. Ecology 85:2960-2970

Huisman J, Matthijs HCP, Visser PM (eds) (2005) Harmful cyanobacteria. Springer-Verlag, Berlin

Kiørboe T, Hansen JLS (1993) Phytoplankton aggregate formation: observations of patterns and mechanisms of cell sticking and the significance of exopolymeric material. J Plankton Res 15:993-1018

Kiørboe T, Anderson KP, Dam HG (1990) Coagulation efficiency and aggregate formation in marine phytoplankton. Mar Biol 107:235-245

Kiørboe T, Lundsgaard C, Olesen M, Hansen JLS (1994) Aggregation and sedimentation processes during a spring phytoplankton bloom: a field experiment to test coagulation theory. J Mar Res 52:297-323

McCave IN (1984) Size spectra and aggregation of suspended particles in the deep ocean. Deep-Sea Res 31:329-352

Oliver RL, Thomas RH, Reynolds CS, Walsby AE (1985) The sedimentation of buoyant Microcystis colonies caused by precipitation with an iron-containing colloid. Proc R Soc Lond B 223:511-28

Plude JL, Parker DL, Schommer OJ, Timmerman RH, Hagström SA, Joers JM, Hnasko R (1991) Chemical characterization of polysaccharide from the slime layer of the cyanobacterium Microcystis flos-aqua C3-40. Appl Environ Microbiol 57:1697-1700

Preston T, Stewart WDP, Reynolds CS (1980) Bloom-forming cyanobacterium Microcystis aeruginosa overwinters on sediment surface. Nature 288:365-367

Reynolds CS, Jaworski GMH, Cmiech HA, Leedale GF (1981) On the annual cycle of the blue-green alga Microcystis 
aeruginosa Kütz. Emend. Elenkin. Phil Trans R Soc Lond B 293:419-477

Sengco MR, Li A, Tugend K, Kulis D, Anderson DM (2001) Removal of red- and brown-tide cells using clay flocculation. I. Laboratory culture experiments with Gymnodium breve and Aureococcus anophagefferens. Mar Ecol Prog Ser 210:41-53

Sengco MR, Hagström JA, Granéli E, Anderson DM (2005) Removal of Prymnesium parvum (Haptophyceae) and its toxins using clay minerals. Harmful Algae 4:261-274

Smayda TJ (1970) The suspension and sinking of phytoplankton in the sea. Oceanogr Mar Biol Annu Rev 8:353-414

Søballe DM, Threlkeld ST (1988) Algal-clay flocculation in turbid waters: variations due to algal and mineral differences. Verh Int Verein Theor Angew Limnol 23:750-754

Staats N, de Winder B, Stal LJ, Mur LR (1999) Isolation and characterization of extracellular polysaccharides from the epipelic diatoms Cylindrotheca closterium and Navicula salinarum. Eur J Phycol 34:161-169

Strycek T, Acreman J, Leppard GG, Nermut MV, Kushner DJ (1992) Extracellular fibril production by fresh-water algae and cyanobacteria. Microb Ecol 23:53-74

Takamura N, Yasuno M, Sugahara K (1984) Overwintering of Microcystis aeruginosa Kütz. in a shallow lake. J Plankton Res 10:283-299

Thomas RH, Walsby AE (1985) Buoyancy regulation in a strain of Microcystis. J Gen Microbiol 131:799-809

Van Duuren FA (1968) Defined velocity gradient model flocculator. J Sanit Eng Div Am Soc Civ Eng 94:671-682

Van Liere L, Mur LR (1978) Light limited cultures of the bluegreen alga Oscillatoria agardhii. Mitt Int Ver Theor Angew Limnol 21:158-167

Editorial responsibility: Edna Granéli, Kalmar, Sweden
Van Olphen H (1977) An introduction to clay colloid chemistry: for clay technologists, geologists and soil scientists. Wiley, London

Verspagen JMH, Snelder EOFM, Visser PM, Huisman J, Mur LR, Ibelings BW (2004) Recruitment of benthic Microcystis (Cyanophyceae) to the water column: internal buoyancy changes or resuspension? J Phycol 40:260-270

Verspagen JMH, Snelder EOFM, Visser PM, Jöhnk KD, Ibelings BW, Mur LR, Huisman J (2005) Benthic-pelagic coupling in the population dynamics of the harmful cyanobacterium Microcystis. Freshw Biol 50:854-867

Verspagen JMH, Passarge J, Jöhnk KD, Visser PM, Peperzak L, Boers P, Laanbroek HJ, Huisman J (2006) Water management strategies against toxic Microcystis blooms in the Dutch delta. Ecol Appl 16:313-327

Visser PM, Ibelings BW, Mur LR (1995) Autumnal sedimentation of Microcystis spp. as a result of an increase in carbohydrate ballast at reduced temperature. J Plankton Res 17:919-933

Visser PM, Ibelings BW, Mur LR, Walsby AE (2005) The ecophysiology of the harmful cyanobacterium Microcystis: features explaining its success and measures for its control. In: Huisman J, Matthijs HCP, Visser PM (eds) Harmful cyanobacteria. Springer-Verlag, Berlin, p 109-142

Waite A, Gallager S, Dam HG (1997) New measurements of phytoplankton aggregation in a flocculator using videography and image analysis. Mar Ecol Prog Ser 155:77-88

Walsby AE (1994) Gas vesicles. Microbiol Rev 58:94-144

Weyhenmeyer GA (1996) The influence of stratification on the amount and distribution of different settling particles in Lake Erken. Can J Fish Aquat Sci 53:1254-1262

Submitted: February 2, 2006; Accepted: April 27, 2006 Proofs received from author(s): August 30, 2006 